Jakub Lipski*

\section{City of Crime}

DOI: http://dx.doi.org/10.12775/LC.2021.036
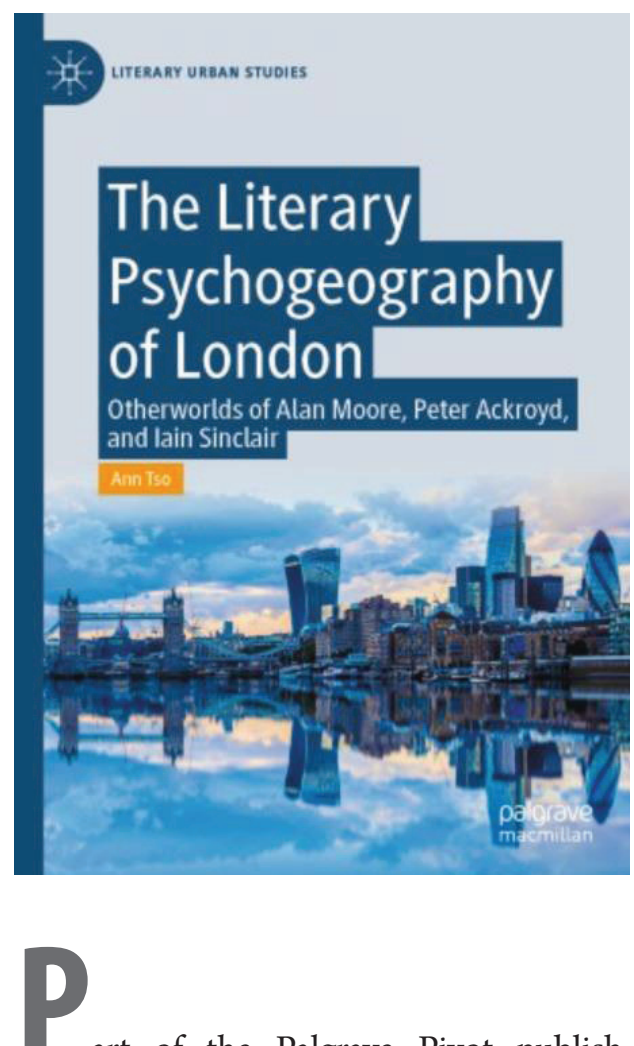

art of the Palgrave Pivot publishing programme, Ann Tso's The Literary Psychogeography of London is a concise "minigraph" of versatile representations of London in contemporary fiction, successfully demonstrating that popular visions of the Londonscape merit sustained critical discussion. In Tso's words, "in seeking to

\footnotetext{
Associate professor at the Faculty of Literary Studies, Kazimierz Wielki University in Bydgoszcz. E-mail: j.lipski@ukw.edu.pl | ORCID: 0000-00030951-3702.
}

capture the London-ness of London, London writers defamiliarize what lies in plain sight, sometimes with the bold ambition to extricate themselves from what is by all appearances a spectacle of consumption" (p. 4).

It is so much more than a curious coincidence that a book on the "literary psychogeography of London", or the "London-ness of London", as Tso repeatedly reminds us, focuses exclusively on crime narratives, as if indirectly suggesting that crime lies at the core of the investigated "London-ness". In this, Tso's study adds to the vibrant field of research into crime fiction's urban settings, recognising, as Heather Worthington succinctly puts it, that "the city and urbanisation are $[\ldots]$ inextricably connected with crime and consequently the genre of crime fiction" (2011: 8).

Informed by recent critical explorations in the field of literary psychogeography, which advocate a new approach to representing space and its impact on character, Tso offers compelling case studies of the graphic novels by Alan Moore (From Hell [1989-98] and Jerusalem [2016]), Peter Ackroyd's Hawksmoor (1985) and Iain Sinclair's White Chappell, Scarlet Tracings (1987) to show how these texts utilize London imagery and the city's genius loci, itself an evasive notion, in transforming the actual urban spaces into an estranging aesthetic quality. Referring to Viktor Shklovsky's theory of art, Tso argues that the disconnected, palimpsestic and ambiguous psychogeographies of Moore, Ackroyd and Sinclair decide about these authors' texts' literariness.

Even if this is not Tso's primary objective, The Literary Psychogeography of London offers relevant insights into postmodern crime fiction, especially - though not called out explicitly - the metaphysical detective story, here exemplified by Ackroyd's and Sinclair's novels, which raises questions 
about "narrative, interpretation, subjectivity, the nature of reality, and the limits of knowledge" (Merivale [\&] Sweeney 1999: 1). When writing about Hawksmoor, Tso insightfully points out that the novel compromises the positivist linear detection not only by the typical postmodern experiments with circular narrative and a lack of satisfying closure, but also by what might be termed vertical detection. She invokes Ackroyd's detective's words that detection is like "rubbing away the grease and detritus which obscured the real picture of the world, in the way a blackened church must be cleaned before the true texture of its stone can be seen" (p. 65). This vertical process, corresponding to the novel's palimpsestic temporal and spatial layering, shows, however, that the "positivist" texture on the bottom, a potential symbol of certitude, is uncannily reminiscent of the grease on the surface.

Tso's other concept is the category of "sensuous detective", driven not by causality and reason, but by the ineffable perceptiveness to the sounds, smells and textures of London. This promising idea, however, seems obfuscated by the author's dense and at times unclear argumentation, unnecessarily mimicking, as it were, Hawksmoor's mannerisms. In a similar way, little can be made of the notion of "psychogeographical detection" defined as "the sensing of a palpable incongruity in a too-congruent water city" (p. 69). One could wish for some more engagement with the recent criticism of Ackroyd's fiction; one obvious point of reference would be Petr Chalupskýs monograph (2016), which also applies the tools and findings of literary psychogeography.

Two of Tso's case studies explore "Ripperature", that is, the now vast corpus of literary representations of Jack the Ripper. Tso skilfully addresses the broader aspects of the Ripper phenomenon: the tourist dimension, the Ripper-haunted Londonscape, the transformations of Whitechapel and the recent, and not so recent, developments in Ripperology. Above all, she aptly recognizes the emblematic role of the Ripper, corresponding to the fact that however versatile and discontinued "London-ness" may appear to be, "the episteme of London, the city that is the heart of England, is a vision realized through murder" (p. 37). What Tso identifies to be driving From Hell's Ripper is in fact a curiously pertinent reflection on how London is typically imagined and represented.

Just as Tso's study of From Hell makes us realize the uncanny connection between murder, vision and historiography, her analysis of Sinclair's White Chappel, Scarlet Tracings draws a parallel between detection and writing, which was also memorably addressed in John Fowles metaphysical crime story "The Enigma” from 1974. Sinclair's novel features the character of "Sinclair", who writes detective stories, but above all becomes, as Tso puts it, "a detective of genius loci” (p. 82). As it is impossible to carry out a systematic investigation of this elusive category, and indeed "Sinclair" writes his psychogeography "in the most paranoid fashion and with the most contrived and contradictory logic" (p. 95), the novel becomes a metafictional commentary on the limits of "positivist" crime fiction, questioning, as Robert Bond points out, "the validity of methods that claim a surety of detection of causes" (p. 94).

Having read Tso's monograph, one is likely to get an impression that her numerous references to "discontinuities", "incompatibility", "defamiliarisation”, "vagueness" and the like, which are meant to characterize the subject matter, are inevitably exemplified by the argument and the writing. But even if one might feel estranged by the convoluted discourse, the reader of crime fiction, recognized here as the key genre to 
understanding the "London-ness of London”, will appreciate Tso's relevant and timely insight into the genre and its social, cultural and psychogeographical implications.

\section{Bibliography}

Chalupský, Petr 2016. A Horror and a Beauty: The World of Peter Ackroyd's London Novels. Prague: Karolinum Press.

Merivale, Patricia [\&] Susan Elizabeth Sweeney 1999. "The Game's Afoot: On the Trail of the Metaphysical Detective Story”. In: Patricia Merivale [\&] Susan Elizabeth Sweeney (eds.). Detecting Texts: The Metaphysical Detective Story from Poe to Postmodernism. Philadelphia: University of Pennsylvania Press. 1-24.

Tso, Ann 2020. The Literary Psychogeography of London: Otherworlds of Alan Moore, Peter Ackroyd, and Iain Sinclair. Cham: Palgrave Macmillan.

Worthington, Heather 2011. Key Concepts in Crime Fiction. Houndmills: Palgrave Macmillan. 